\author{
A.M. Digarbaeva* ${ }^{(i)}$, A.N. Kaliyeva ${ }^{(i)}$, Nurmanbek Aidyn \\ Kazakh National Women's Teacher Training University, Kazakhstan, Almaty \\ *e-mail: asema_1985.kz@mail.ru
}

\title{
STUDY OF THE HEAVY METALS EFFECT ON THE PIGMENT SYSTEM OF CORN VARIETIES
}

\begin{abstract}
Heavy metals are metals that are toxic to organisms when released into the environment in large quantities. In recent years, this term refers only to the following elements: lead, zinc, cadmium, mercury, molybdenum, manganese, nickel, tin, cobalt, titanium, copper, vanadium.

The article deals with the current pollution of the environment, as well as the use of measures to combat plants that are resistant to this herd. In addition, the adaptation degree of plants to changes in environmental factors, new environmental conditions depends on the composition of chlorophylls and carotenoids, which are the main photoreceptors of photosynthetic cells. However, the exposure degree of plants to the pigment complex depends on the type of plant, growth conditions, the composition and concentration of toxicants and the duration of their action. An overview of the research presented in the general article shows that heavy metals have a significant negative impact on plant growth. The study of plants, especially those used for food purposes, is very important in the maximum prevention of these processes. In this regard, the purpose of the study was to determine the effect of heavy metals on the pigment system of corn varieties. We observed the effect of heavy metal ions on photosynthetic pigments, resistant and intolerant varieties of 14-day-old corn varieties (Turan-170, Turan-480, Kazakhstan-435, Tauelsizdik-20). During the experiment, we concluded that the varieties Turan-170, Turan-480, Tauelsizdik-20 are resistant to corn in terms of the content of carotenoids, chlorophyll-a, chlorophyll-b pigments in corn varieties, and Kazakhstan-435 is intolerant. This is because Kazakhstan-435 may have varietal characteristics.

In general, heavy metals have a negative effect on plants, reduce the content of chlorophyll and carotenoids, cause shifts in the structure of chloroplast membranes, which negatively affects the intensity of photosynthesis.
\end{abstract}

Key words: chlorophyll, carotenoids, pigment, heavy metal, photosynthesis, cadmium, corn, plants.

\author{
А.М. Аигарбаева*, А.Н. Калиева, Нұрманбек Айдын \\ Қазақ ұлттық қыздар педагогикалық университеті, Қазақстан, Алматы қ. \\ *e-mail: asema_1985.kz@mail.ru \\ Жүгері сорттарының пигмент жүйесіне \\ ауыр металдардың әсерін зерттеу
}

\footnotetext{
Ауыр металдар - қоршаған ортаға көп мөлшерде түскенде организмдерді уландыратын металдар. Бұл терминмен соңғы жылдары тек қана мынадай элементтер: қорғасын, мырыш, кадмий, сынап, молибден, марганец, никель, қалайы, кобальт, титан, мыс, ванадий аталады.

Мақалада қазіргі таңда қоршаған ортаның ластануы, сонымен қатар осы ортада төзімділік беретін өсімліктермен ауылшаруашылық,дақылдары арқылы күресу шараларын қолдану. Сонымен қатар өсімдіктер қоршаған орта факторларының өзгеруіне, жаңа экологиялық жағдайларға бейімделу дәрежесі фотосинтетикалық жасушаның негізгі фоторецепторлары болып табылатын хлорофиялдер мен каротиноидтардың құрамына байланысты. Алайда өсімдіктердің пигмент кешеніне әсер ету дәрежесі өсімдіктің түріне, өсу жағдайларына, токсиканттардың құрамы мен концентрациясына және олардың әсер ету ұзақтығына байланысты. Жалпы мақалаАа келтірілген зерттеу жұмыстарына шолу жасау барысында, ауыр металдардың өсімдіктердің өсіп-дамуына айтарлықтай кері әсері байқалады. Осы процестердің барынша алдын алуда, әсіресе азықтүліктік мақсатта пайдаланылатын өсімдіктерді зерттеу өте өзекті болып табылады. Осы орайда зерттеу жұмысының мақсаты - жүгері сорттарының пигмент жүйесіне ауыр металдардың әсерін анықтау. 14 күндік жүгері сорттарына (Тұран-170, Тұран-480, Қазахстан-435, Тәуелсіздік-20) ауыр метал иондарының фотосинтез пигменттеріне әсерін, төзімді және төзімсіз сорттарды байқадық. Тәжірибе жүргізу барысында жүгері сорттарында каратиноил, хлорофим^-а, хлорофил^-b пигменттерінің көрсеткіштерінің мөлшері бойынша Тұран-170, Тұран-480, Тәуелсіздік-20 сорттары төзімді, Қазахстан-435 сорты төзімсіз деп тұжырымдадық. Себебі Қазахстан-435 сорттық, ерекшелігі де болуы мүмкін.
} 
Жалпы ауыр металдар өсімдіктерге кері әсер етеді, хлорофилм мен каротиноидтардың құрамын төмендетеді, хлоропласттар мембраналарының құрылымында ығысулар тудырады, бұл фотосинтездің қарқындылығына теріс әсер етеді.

Түйін сөздер: хлорофил^, каротиноид, пигмент, ауыр метал, фотоситез, кадмий, жүгері, өсімдіктер.

\title{
А.М. Аигарбаева*, А.Н. Калиева, Нурманбек Айдын
}

Казахский национальный женский педагогический университет, Казахстан, г. Алматы

*e-mail: asema_1985.kz@mail.ru

\section{Изучение влияния тяжелых метаммов на пигментную систему сортов кукурузы}

\begin{abstract}
Тяжелые металмы - это металмы, которые токсичны Аля организмов при попадании в окружающую среду в больших количествах. В последнее время этим термином обозначаются только следующие элементы: свинец, цинк, кадмий, ртуть, молибден, марганец, никель, олово, кобальт, титан, медь, ванадий.

В статье рассматривается современное загрязнение окружающей среды, а также применение мер борьбы с растениями, устойчивыми к этой среде. Кроме того, степень адаптации растений к изменениям факторов окружающей среды, новымусловиям среды зависит от составахлорофилмов и каротиноидов, которые являются основными фоторецепторами фотосинтетических клеток. ОАнако степень воздействия на растения пигментного комплекса зависит от вида растения, условий роста, состава и концентрации токсикантов и продолжительности их действия. Обзор исследований, представленных в общей статье, показывает, что тяжелые металмы оказывают значительное негативное влияние на рост растений. Изучение растений, особенно используемых в пищевых целях, очень важно Аля максимальной профилактики этих процессов. В связи с этим целью исследования бы^о определение влияния тяжелых металмов на пигментную систему сортов кукурузы. Мы наблюдали влияние ионов тяжелых металмов на фотосинтетические пигменты, устойчивые и непереносимые сорта 14-дневных сортов кукурузы (Туран-170, Туран-480, Казахстан-435, Тауелсиздик-20). В ходе эксперимента сделан вывод, что сорта Туран-170, Туран-480, Тауелсиздик-20 устойчивы к кукурузе по содержанию каротиноидов, хлорофилма-а, пигментов хлорофимла-b в сортах кукурузы, а Казахстан-435 - нетерпимы. Это связано с тем, что Казахстан-435 может иметь сортовые характеристики.

В целом тяжелые метамлы негативно действуют на растения, снижают содержание хлорофияла и каротиноидов, вызывают сАвиги в структуре мембран хлоропластов, что отрицательно сказывается на интенсивности фотосинтеза.
\end{abstract}

Кмючевые слова: хлорофим^, каротиноид, пигмент, тяжелый метал^, фотосинтез, кадмий, кукуруза, растения.

\section{Introduction}

One of the main pollutants currently observed in all natural environments is heavy metals. This is partly due to the biological activity of metals. In addition, they do not undergo transformation like organic compounds, and are stored for a long time when entering the biochemical cycle [1].

Contamination of the soil over the natural level by $\mathrm{Pb}, \mathrm{Zn}, \mathrm{Cr}$ and $\mathrm{Co}$ could be one of the indicators of anthropogenic environmental pollution. Fast development of industry, continuously increasing population, and intensification of road traffic are regarded as the foremost causes of ecosystem pollution in urban areas [2].

Heavy metals, such as cadmium, copper, lead, chromium and mercury are major environmental pollutants, particularly in areas with high anthropogenic pressure. Heavy metal accumulation in soils is of great concern in agricultural production due to the adverse effects on food safety and marketability, crop growth due to phytotoxicity, and environmental health of soil organisms. The influence of plants and their metabolic activities affects the geological and biological redistribution of heavy metals through pollution of the air, water and soil. A common consequence of heavy metal toxicity is the excessive accumulation of reactive oxygen species (ROS) and methylglyoxal (MG), both of which can cause peroxidation of lipids, oxidation of protein, inactivation of enzymes, DNA damage and/or interact with other vital constituents of plant cells. This review focuses on effect of heavy metals on plant growth, yield and their mode of toxic effects in plants[3].

In the case of certain eco groups of the environment, the highest concentration of heavy metals is in the soil, which is primarily caused by the atmosphere. Heavy metals often enter the atmosphere 
as dust that rises from the ground. Therefore, when snow and rain fall from the atmosphere to the earth's surface, they often contain lead, cadmium, arsenic, etc. elements. The main pollutants are power plants, smelters, the oil industry, construction metals companies and automobiles. Nitrogen, lead oxides, hydrocarbons, etc. are used during the operation of internal combustion engines. substances are released and fall to the soil surface. In this case, after the substances enter the soil, the substance enters the circulation through the food chain.

Toxins accumulate in the soil, causing changes in its chemical composition, which disrupts the unity of living organisms and the environment [4].

Common source of soil and plant contamination with heavy metals is traffic [5].

Heavy metals are among the most serious environmental pollutants due to their high toxicity, abundance and ease of accumulation by various plant and animal organisms. Persistent increase of heavy metals in harbour sediments can be attributed to the contribution of effluent from waste water treatment plants, industries, mining, power stations, agriculture [6]

Studied environmental risk assessment and remediation of soils contaminated due to waste disposal from tannery industries in Tamil Nadu and Kanpur (India), [7].

The accumulation risk of heavy metals in soil and vegetable crop irrigated with sewage water in a specific area of Saudi Arabia [8]. The contaminated soil effected by pollutants and toxic metals on edible plants irrigated by sewage water in their various studies [9-10].

Heavy metals are metals that poison organisms when released into the environment in large quantities. In recent years, this term refers only to the following elements: lead, zinc, cadmium, mercury, molybdenum, manganese, nickel, tin, cobalt, titanium, copper, vanadium. When these elements enter the environment, they do not decompose in the process of self-cleaning of ecosystems. They accumulate in the soil, pass on to plants and then enter the biological cycle. Biological chain: soil - plant - man, soil - water - man and soil - atmospheric air - are known to pass through the human body and cause various diseases.

Many regions of the country are polluted with gaseous, liquid and solid industrial wastes, sulfates and heavy metals. Due to the high pollution level of the environment with harmful substances, special attention is paid to the study of their impact on soil, water, air, damage and biological role. Large amounts of various chemical compounds and heavy metals fall into the soil of the areas where the production centers are located. Soil resources are one of the most important prerequisites for life on earth. However, we do not appreciate its true significance and role. Soil is one of the components of the biosphere, a biochemical environment for humans, animals and plants, which is a very high energy reserve, a very important reserve of mechanisms of self-cleaning processes that can balance the direct and indirect effects of soil biota and humans. The conditions necessary for the production of food for humans and animal feed are created only through the soil. Soil is a natural resource that cannot be exchanged for anything. To date, science has not yet been able to find artificial material that can replace soil. No method of growing plants without soil can play the soilrole. Therefore, the most important issue facing human society and still remains important is to create the best conditions for the spontaneous regeneration and preservation of soil in the soil formation process [11].

The accumulation of heavy metals in plants depends on the specifics of each species. Studies have shown that the amount of heavy metals in soils and plants in the area close to copper smelting is much higher than in the control area. The amount of copper increases up to 12 times, and the amount of other elements increase up to 2-5 times. In addition, the content of heavy metals other than zinc is much higher in the soil than in plants. However, if the amount of heavy metals in the soil increases by 2-3 times, their content in plants increases by 5-6 times. According to statistical analysis, there is a direct correlation between soil and plants [12]. Morphopatho genesis of leaves and all plants is observed in the ventilated area of harmful residues. Damage to the leaves is observed in the form of necrosis with changes in shape and color, as well as chlorosis, jaundice, loss of turgor, withering without discoloration, falling without change or slight external damage [13].

The presence of heavy metals in water degrades their quality, which eventually affects human health [14].

Industrial dust in heavily polluted areas also has a significant negative impact on plants. Large particles of dust $(5-10 \mathrm{~m} / \mathrm{km})$ mechanically affect the surface organs of plants. In addition to damaging the buds, flowers, and leaves (cutting), the dust can also damage the bark, causing it to crack and peel. Peeled wood loses water in the body and begins to dry out, the function of potassium is impaired, ie the viability of the whole plant organism decreases [15]. 
Heavy metals in the soil refers to some significant heavy metals of biological toxicity, including mercury $(\mathrm{Hg})$, cadmium $(\mathrm{Cd})$, lead $(\mathrm{Pb})$, chromium $(\mathrm{Cr})$, and arsenic (As), etc. With the development of the global economy, both type and content of heavy metals in the soil caused by human activities have gradually increased in recent years, which have resulted in serious environment deterioration

The toxicity of heavy metals is manifested in many ways when plant cells accumulate them at high levels. Heavy metals can be divided into two groups: redox active $(\mathrm{Fe}, \mathrm{Cu}, \mathrm{Cr}, \mathrm{Co})$ and redox inactive $(\mathrm{Cd}, \mathrm{Zn}, \mathrm{Ni}, \mathrm{Al}$, etc.). The redox active heavy metals are directly involved in the redox reaction in cells and result in the formation of $\mathrm{O} 2 \cdot-$ and subsequently in $\mathrm{H} 2 \mathrm{O} 2$ and $\bullet \mathrm{OH}$ production via the HaberWeiss and Fenton reactions (Schutzendubel and Polle, 2002). Exposure of plants to redox inactive heavy metals also results in oxidative stress through indirect mechanisms such as interaction with the antioxidant defense system, disruption of the electron transport chain, or induction of lipid peroxidation[16].

Recently, self-cleaning of ecosystems, even if the influx of heavy metals into them has stopped, is due to the excessive amount of metals that have accumulated in the soil and are fixed in its stable components.

Plants with weakened immunity due to natural stresses are highly sensitive to anthropogenic pollution. When alfalfa is exposed to a solution containing zinc and cadmium, its growth slows down, causing symptoms of chlorosis and necrosis between the nerves [17].

Metals cause a wide range of genetic changes. One metal cell can damage several places. For example, cadmium damages DNA molecules, destroys lysosomes, inhibits DNA repair, disrupts the synthesis of replication enzymes, changes the structure of DNA. High levels of copper alter conformation and stimulate DNA and RNA synthesis $[18,19]$. The reaction of plant species to heavy metals is observed at all levels of organization, i.e. at the cellular, organic and population levels. At the cellular level, there is a change in the activity of cell membrane damage as a common stress associated with excess heavy metals. At the organismal level, morphological and physiological lesions are observed in individual parts of the plant, i.e. necrosis of leaves, changes in shape, shoots withering, plant growth slowing. In damaged leaves, the covering tissue and mechanical tissue, the cell layer of the epidermis is weakly developed and the cuticle is thin, the full development cycle is disrupted under the industrial pollution influence [20].
It can be concluded that, besides the anthropogenic pollution, which is reflected in the excessive use of plant protection products and fertilizers, and also the impact of air pollution from motor vehicles in certain sections of the examined area, the dominant influence on concentration of some examined elements comes from geochemical composition of parent material from which the soils were developed. [21].

Copper is a trace element necessary for plant life. However, excessive accumulation of copper in the plants body slows down the development and growth of the root system, slow growth of above-ground plants parts and pale leaf tips. As a result of pathological changes caused by excess copper, the yield of cultivated plants decreases sharply [22].

Large amounts of cadmium have been found in plants growing along highways. A similar situation is observed in plants grown near industries that pollute the environment with this toxicant. Accumulation signs of excess cadmium are reddish-brown color of the tips and tips of the plant leaves. The leaves shrink or fall off, the plants growth slows down. If the amount of cadmium in the soil exceeds $30 \mathrm{mg} /$ $\mathrm{kg}$, it destroys plant life. Large amounts of cadmium are released into the soil during the extraction and processing of zinc ores $[23,24]$. Plant growth inhibition due to cadmium is due to the weakening of the photosynthesis process. The presence of $96 \mathrm{mg}$ of cadmium in $1 \mathrm{~kg}$ of leaves reduces the growth rate by $50 \%$ [26].

A review of the above research shows that heavy metals have a significant negative impact on plant growth. In the maximum prevention of these processes, the study of plants, especially those used for food purposes, is very important. In this regard, the purpose of the study is to study the effect of heavy metals on the pigment system of corn varieties.

\section{Object and method of research}

Object of research: varieties of corn (Zea mays): Turan-170, Turan-480, Kazakhstan-435, Tauelsizdik-20.

As heavy metals: copper - $\mathrm{CuSO} 4$ and $\mathrm{CdSO} 4$ - solutions of cadmium of different concentrations (3 mg/1, $5 \mathrm{mg} / 1,10 \mathrm{mg} / \mathrm{l})$ and $175 \mathrm{ml}$ of distilled water $\mathrm{H} 2 \mathrm{O}$ were obtained in each container.

In order to determine the effect of heavy metals in water on the corn plant, copper -CuSO4 and CdSO4-cadmium are grown, the required amount of seeds from 4 varieties is taken for control and cleaned several times with distilled water. In addi- 
tion, in order to clean the grain from harmful microorganisms, corn seeds are soaked in a solution of potassium permanganate $(\mathrm{KMnO} 4)$ for $10 \mathrm{~min}$ utes and shaken again with distilled water. Grains of corn varieties are prepared in three versions in 50 pieces in containers filled with salt solution of different concentrations. The germination energy was monitored for 3 days, 5 days and 7 days from the date of sowing of corn varieties, and the amount of pigment was determined for 14 days of germination.

To obtain an alcoholic solution of pigments, 20 $\mathrm{mg}$ of leaf was crushed in a porcelain dish to obtain a light and homogeneous mass. The precipitate was poured into centrifuge tubes, shaken with $2 \mathrm{ml}$ of 90\% alcohol, and centrifuged for 7 minutes at 6-7 thousand revolutions. The liquid on the surface of the centrifuge tubes was poured into a $10 \mathrm{ml}$ test tube and all the liquid in the test tube was made up to the same volume, and the pigment content of this solution was determined spectrophotometrically [26]. Chlorophyll concentration was determined by spectrophotometric analysis on a photometer-KFK-3, chlorophyll "a" and chlorophyll "b" according to the following Vernon formula.

$$
\begin{gathered}
\mathrm{C}_{\text {хл А }}=11,63 * \mathrm{D}_{665}-2.39 * \mathrm{D}_{649} \\
\mathrm{C}_{\text {хл }} \mathrm{B}=20.11 * \mathrm{D}_{649}-5.18 * \mathrm{D}_{665} \\
\mathrm{C}_{\text {хл А хал } \mathrm{B}}=6.45 * \mathrm{D}_{665}+17.72 * \mathrm{D}_{649}
\end{gathered}
$$

where: $\mathrm{C}-\mathrm{a}, \mathrm{b}$ chlorophylls and carotenoid concentrations $\mathrm{mg} / \mathrm{l}$,

$$
\text { D-wavelengths } 440.5 ; 649 ; 665 \mathrm{~nm} \text {, }
$$

The amount of carotenoids was calculated according to the Holm-Vetstein formula.

$$
\mathrm{C}_{\text {кар }}=4,695 \mathrm{D}_{440.5}-0.268 \mathrm{C}_{(\text {хл.а } а \text { хлл) }}
$$

After determining the concentration of pigments in the extract, taking into account the weight (mass) of the test material and the volume of the extract, the amount of pigments in the test material was determined by the following formula:

$$
\mathrm{A}=\mathrm{C} * \mathrm{~V} / \mathrm{P} * 1000
$$

where, the concentration of pigments obtained in C-mg / 1;
Volume of V-pigment extract in $\mathrm{ml}$;

A-mg / g weight of pigments in plant material;

P-weight of plant material / gram.

In the laboratory, the yield and growth energy of corn varieties were determined 14 days after planting.

\section{Results and Discussion}

In general, heavy metals have a negative effect on plants, reduce the content of chlorophyll and carotenoids, cause shifts in the structure of chloroplast membranes, which negatively affects the intensity of photosynthesis [27].

Toxic effects of heavy metals on plants: disruption of growth processes, cell division, developmental disorders and morphological structures; free radical oxidation and lipid peroxidation, inhibition of photosynthetic processes in plants and damage to the photosynthetic apparatus [28].

Of great importance in the study of the state of plants is the study of the amount of pigment during photosynthesis and its ability to adapt to changes in environmental conditions. Certain indicators of the plant's response to changes in environmental conditions, the degree of their adaptation to new environmental conditions, the presence of the main photosynthetic photoreceptors in the cell, the amount of chlorophyll and carotenoids [11].

The amount of pigment in the leaves obtained from 14-day-old shoots of Turan-170 variety was significantly lower than in the control variant (control $3.3>3 \mathrm{mg} / \mathrm{g} .2 .63>5 \mathrm{mg} / \mathrm{g} .1 .81>10 \mathrm{mg} / \mathrm{g}$. $1.41)$. . It is obvious that the value of chlorophyll-a depends on heavy metal ions, because the value of chlorophyll-a began to decrease (control 14.85> 3 $\mathrm{mg} / \mathrm{g} .14 .91>5 \mathrm{mg} / \mathrm{g} .13 .7>10 \mathrm{mg} / \mathrm{g} .13 .48$. $>$ ). Chlorophyll-b was reduced compared to the control version and at a concentration of $10 \mathrm{mg} / \mathrm{g}$ chlorophyll-b pigment $5 \mathrm{mg} / \mathrm{g}$ con. (control $15.12>3 \mathrm{mg}$ / g. $12.5>5 \mathrm{mg} /$ g. $7.4>10 \mathrm{mg} /$ g. 9.59). That is, Turan-170 variety is resistant to heavy metal ions (Figure 2).

The amount of pigment in the 14-day leaf growth of Turan-480 was declining. Caratinoid, chlorophyll a and $\mathrm{b}$ pigment levels decreased from top to bottom with control values of $4.78>3 \mathrm{mg} /$ $\mathrm{g}>3.89,5 \mathrm{mg} / \mathrm{g}>3.48,10 \mathrm{mg} / \mathrm{g}>2.92$. Due to the action of heavy metal ions, Turan-480 is resistant (Figure 3). 

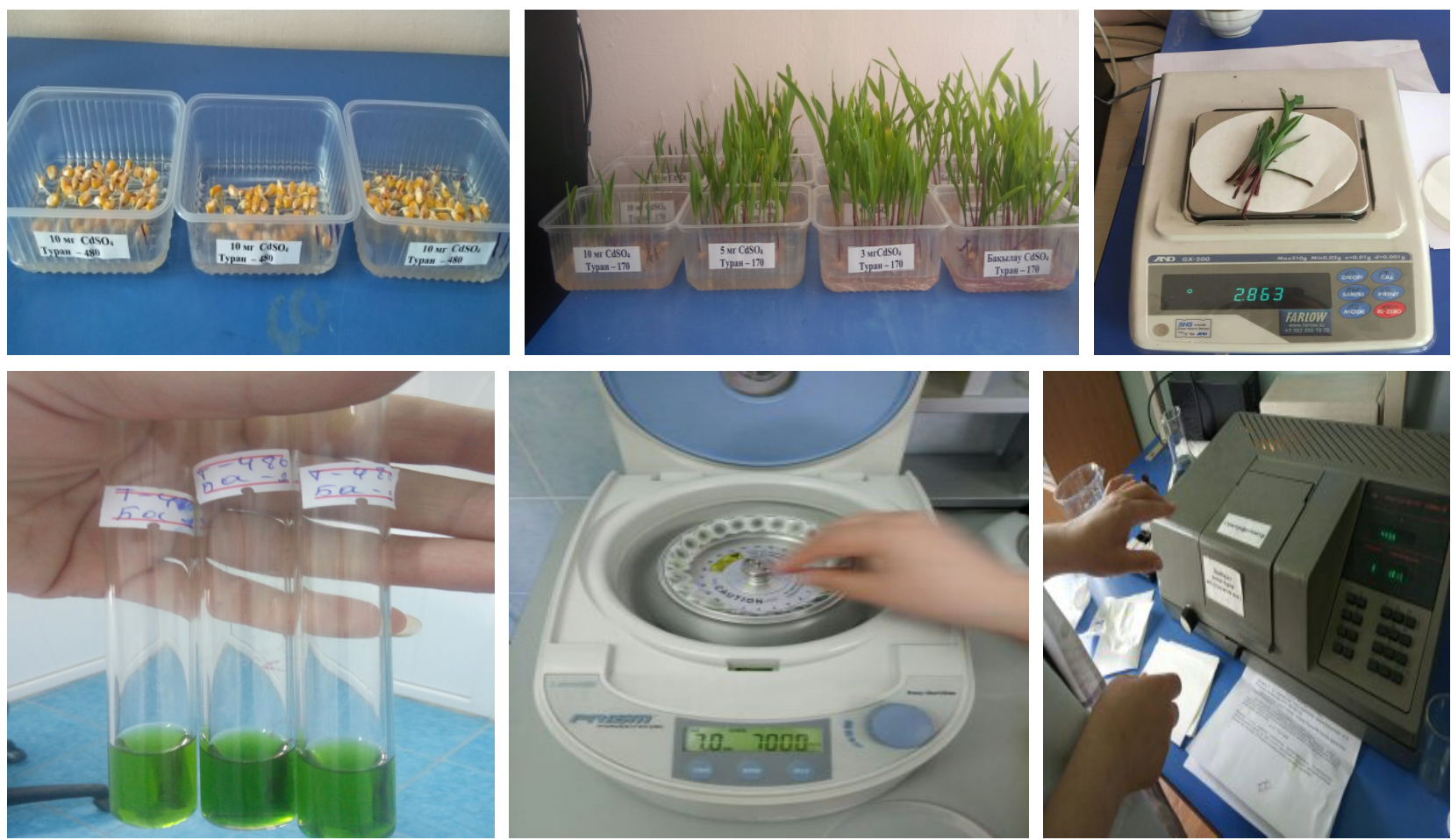

Figure 1 - The course of experimental work to determine the effect of heavy metals on the pigment system of corn varieties in the laboratory

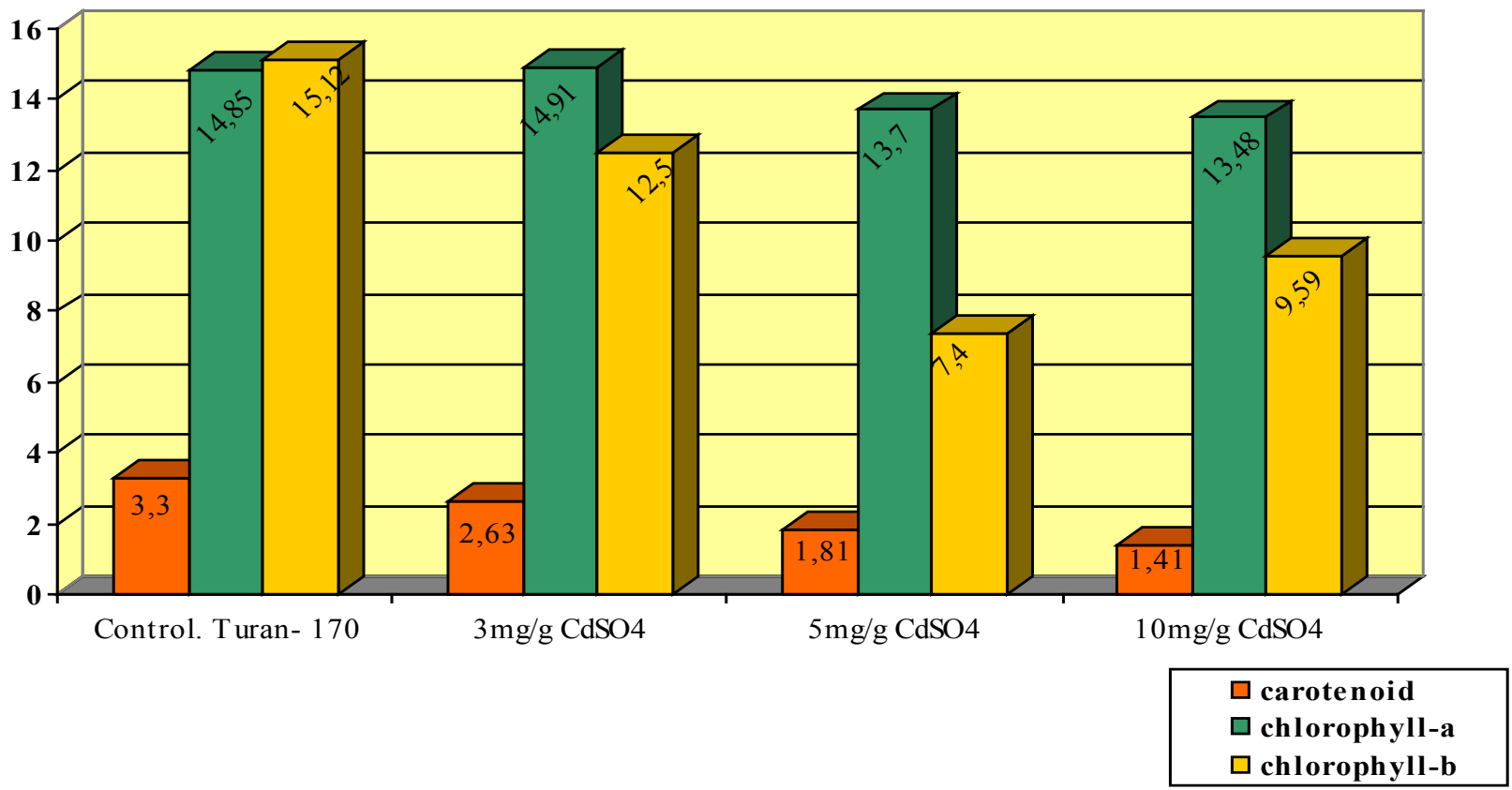

Figure 2 - The effect of cadmium sulfate on photosynthetic pigments in 14-day-old seedlings of Turan-170. 


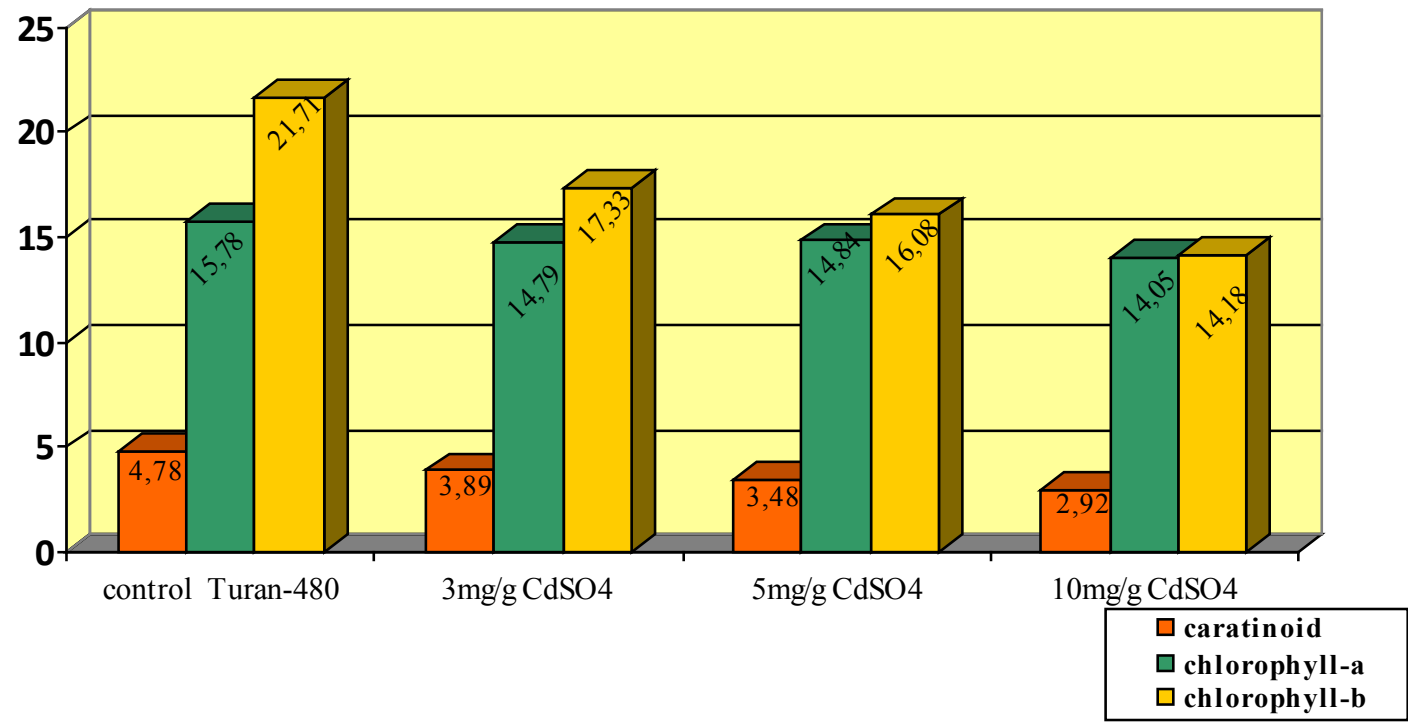

Figure 3 - The effect of cadmium sulfate on photosynthetic pigments in 14-day seedlings of Turan-480.

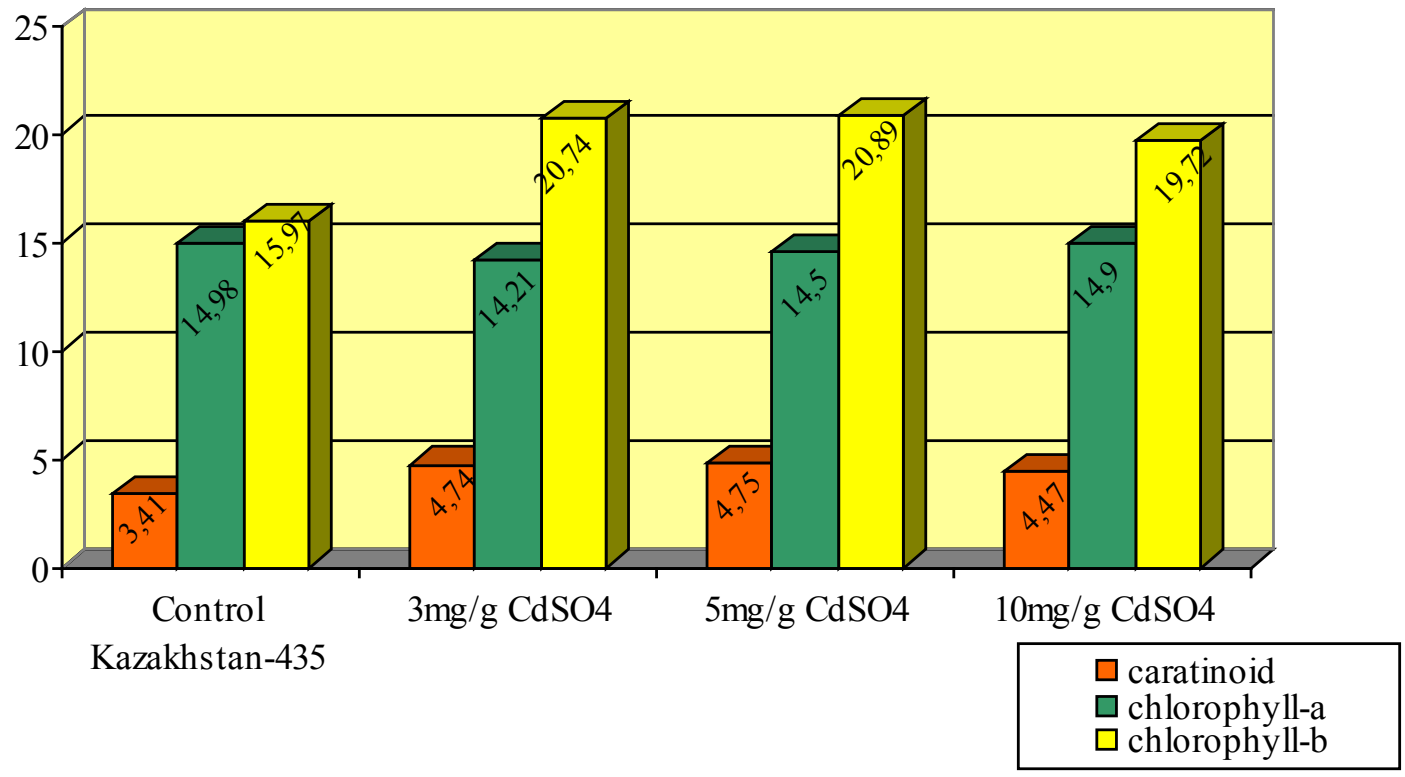

Figure 4 - The effect of cadmium sulfate on photosynthetic pigments in 14-day seedlings of Kazakhstan-435 variety.

Pigment levels in the leaf samples of Kazakhstan-435 varied, the chlorophyll-b value increased compared to the control version, because during the experimental control, the leaves of Kazakhstan-435 variety began to turn yellow after 10 days, i.e. intolerance to heavy metal ions (Fig. 4).

The pigment in the leaves of the Tauelsizdik-20 corn variety decreased in the amount of carotenoids, chlorophyll-a, chlorophyll-b (Figure 5).
As can be seen from the data in the diagram, it is clear that the photosynthetic pigments in the seedlings of corn varieties depend on the concentration of heavy metals.

Compared to the control version, it is clear that the synthesis of photosynthetic pigments in the seedlings of cadmium sulfate Turan-170, Turan-480, Tauelsizdik-20 varieties decreased under the influence of heavy metals. 


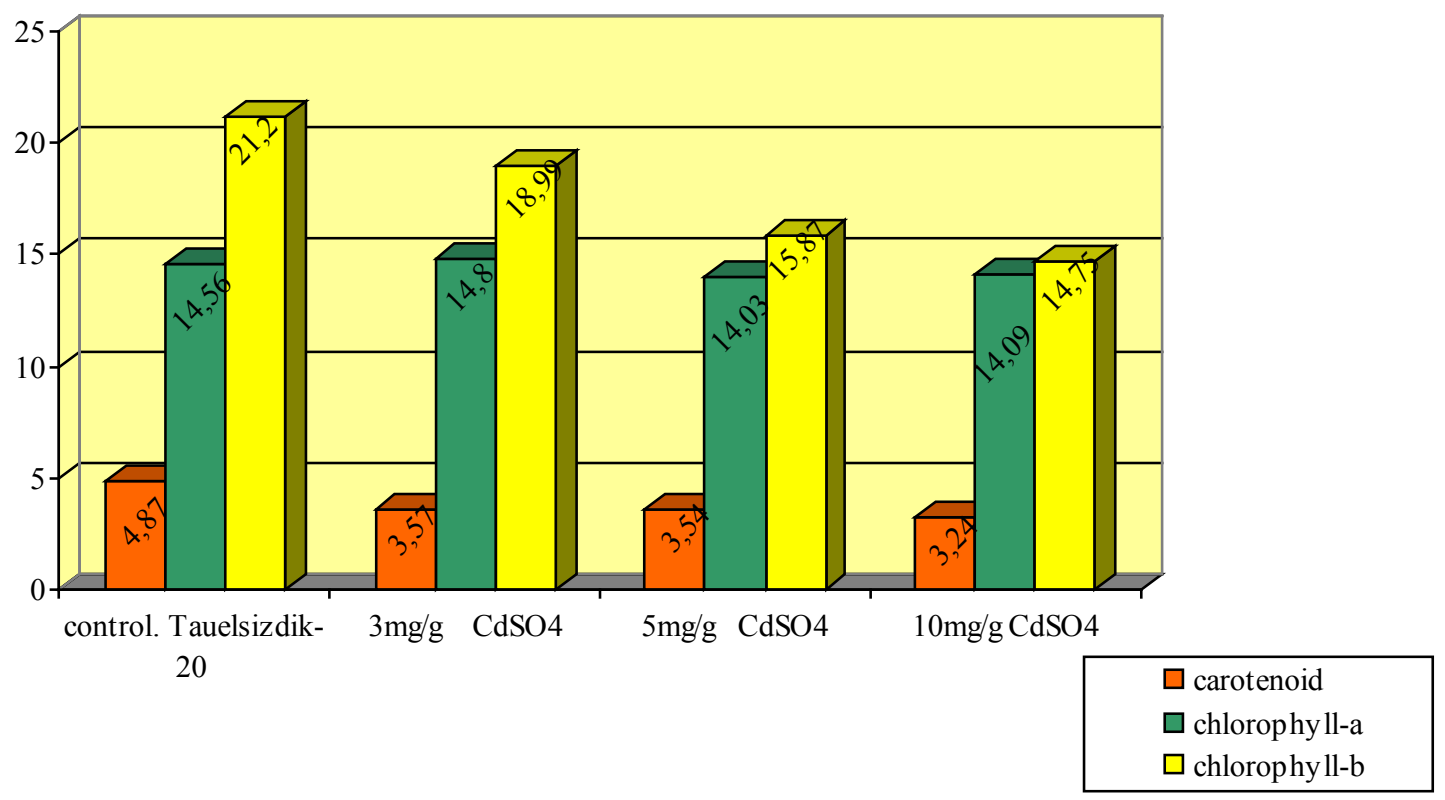

Figure 5 - The effect of cadmium sulfate on photosynthetic pigments in 14-day seedlings of Independence-20 variety.

Compared to the control version, the concentration of carotenoids decreased from 3.3 to $1.18-1.41$ $\mu \mathrm{g} / \mathrm{g}$. However, as the concentration of the heavy metal increased, the effect of the heavy metal became more pronounced.

Such indicators are clearly reflected in the varieties Turan-480, Tauelsizdik-20. Only, an increase in the synthesis of FS (photosynthetic) pigments of Kazakhstan -435 variety (caratinoid control from 3.14 to $4.74-4.47 \mu \mathrm{g} / \mathrm{g}$ ) and (Hl$\mathrm{v}$ from 15.97 to $20.74-19.72 \mu \mathrm{g} / \mathrm{g}$ ) may have varietal characteristics of plants. In general, we observed in experiments that the growth and germination of corn varieties undergo $10 \mathrm{mg} / \mathrm{g}$ of cadmium sulfate is subject to physiological changes. It can occur due to dehydration of the leaf blade under the influence of salts of heavy metals. Such physiological processes need to be identified by individual studies. So, to summarize, the corn varieties include Turan-170, Turan-480, Tauelsizdik-20 heavy metal-resistant varieties. Kazakhstan- 435 variety exceeded the control version, as mentioned above, the leaves were dark green, pink-brown, ie did not show resistance to heavy metal ions.

\section{Conclusion}

The effect of heavy metal (CdSO4) on the composition of photosynthetic pigments in corn varieties. In general, heavy metals were obtained to determine the composition of photosynthetic pigments and resistant and non-resistant varieties of corn (Turan-170, Turan-480, Tauelsizdik-20, Kazakhstan-435). Due to the increase in the concentration of $\mathrm{CdSO} 4$, the concentration of chlorophyll a and $\mathrm{b}$, carotenoids decreased. We noticed that the photosynthetic pigments Turan-170, Turan-480, Tauelsizdik-20 had a higher content of resistant corn than Kazakhstan-435, which is not resistant to heavy metals. The composition of photosynthetic pigments directly affects the rate of photosynthesis, ie determines the productivity of crops. The composition of photosynthetic pigments is an indicator of plants resistant to growing in an unfavorable environment (control version $3 \mathrm{mg} / \mathrm{g}, 5 \mathrm{mg} / \mathrm{g}, 10 \mathrm{mg} / \mathrm{g}$ ).

\section{References}

1 Тулебаев Р.К., Хроническая свинцовая интоксикация. - Алматы: Ғылым, 1995. - с.9-11.

2 Jankiewicz, B. and D. Adamczyk ,2010 Assessing Heavy Metal Content in Soils Surrounding a Power Plant. Short communication, Polish Journal of Environmental Studies, 19 (4): 849-853

3 Mukti Gill. Heavy metal stress in plants: a review. International Journal of Advanced Research ISSN 2320-5407 (2014), Volume 2, Issue 6, 1043-1055 
4 Нұрғызарынов А., Атыраулық экотоптардың химиялық экологиясы (Сырдың төменгі ағысы). - Қызылорда.: «Тұмар», 2003

5 Gworek, B., A. Deckowska and M. Pierscieniak, 2011.Traffic Pollutant Indicator: Common Dandelion (Teraxacum Officinale), Scots Pine (Pinus Silvestris), Small-Leavud Lime (Tilia Cordata). Polish Journal of Environmental Studies, 20 (1): 87-92.

6 Guevara-Riba A, Sahuquillo A, Rubio R, Rauret G (2004) Assessment of metal mobility in dredged harbour sediments from Barcelona, Spain. Sci Total Environ 321: 241-255.

7 SrinivasaraoCh, Venkateswarlu B, Rattan Lal (2012) Sustaining agronomic productivity and quality of a Vertisolic soil (Vertisol) under soybean-safflower cropping system in semi-arid central India. Canadian Journal of Soil Science 92(5): 771-785.

8 Alghobar MA, Suresha S (2017) Evaluation of metal accumulation in soil and tomatoes irrigated with sewage water from Mysore city, Karnataka, India. Journal of the Saudi Society of Agricultural Sciences 16(1): 49-59.

9 Ansari MI, Malik M (2007) Biosorption of nickel and cadmium by metal resistant bacterial isolates from agricultural soil irrigated with industrial wastewater. Bioresour Technol 98(16): 3149-3153.

10 Aslam J Khan SA, Khan SH (2013) Heavy metals contamination in roadside soil near different traffic signals in Dubai, United Arab Emirates, Journal of Saudi Chemical Society 17(3): 315-319.

11 Тужилкина В.В. Реакция пигментной системы хвойных на длительное аэротехногенное загрязнение./Экология, 2009, № 4, с. 243-248

12 Артамонов В.И. Растения и чистота природной среды. - Москва: Наука, 1986. -с.27-34.

13 Романова СМ., Нурахметов Н.Н., Батаева К.О. Экологические аспекты загрязнения токсичными веществами поверхностных вод Казахстана // Химия. Охрана окружающей среды. Экология человека. — 1997. N4. - C.42.

14 Shalini Arora, C K Jain and R S Lokhande. Review of Heavy Metal Contamination in Soil .International Journal of Environmental Sciences \& Natural Resources ISSN -2572-1119. July 31, 2017. 3Int J Environ Sci Nat Res 3(5): IJESNR. MS.ID.555625 (2017)

15 Давидович Г.Т., Сахатов Г.С, Давидович С.Г. Региональное загрязнение природной среды Актюбинской обл. // Химия. Охрана окружающей среды. Экология человека. - 1996. -N3-4. -C.72.

16 Chao Su, LiQin Jiang, WenJun Zhang. A review on heavy metal contamination in the soil worldwide: Situation, impact and remediation techniques Environmental Skeptics and Critics, 2014, 3(2): 24-38 IAEES www.iaees.org

17 Рахыпбеков Т.К. Роль гигиенических факторов экологическине благополучного города в совершенствовании системы управления здравохранением. //Автореферат канд.диссерт. - Алматы, 1996.

18 Савельев М.Б. Экофизиологические исследования фитотронов для разработки методов контроля загрязнения водной среды тяжелыми металлами./ Вестник Московского Университета. - 1999. Серия 16, -N2. -C.42-47.

19 Кабате- Пендиас А. Микроэлементы в почвах и растениях. - М., 1989. -8-204 с.

20 Дубинин Н.П., Засухина Г.Д. Защитные механизмы клетки в условиях загрязнения окружающей среды // Вестник АН CCCP. М., 1975. -N11. -C.76-77.

21 R. PiviC, A. StanojkoviC-Sebi C, D. JoSi C and Z. DiniC . Evaluation of the heavy metals content in soil and plant material at different distances from the motorway E75 in the section Belgrade-PreSevo (SERBIA) .Bulgarian Journal of Agricultural Science, 20 (No 2) 2014, 330-336 Agricultural Academy

22 Битнерович А // Охрана природы и воспроизводства приподных ресурсов М 1999 № 4 С-45.

23 Бахиев А. Воздействие буревых рпабот на растительность //Воздействие техногенных факторов на растительный покров Каракалпакстана ташкент 1992, С 68-83.

24 Микшевич Н.В. Ковальчук Л.А. тяжелые металлы в системе посева растения животные в зоне действия медплавильного предприятия // Матер 2-ой всесоюзной междунаодной конференции по ТМ в окр и охр. Природы М. 1988 г С 127 129.

25 Дубинин Н.П. Засухина Г.Д. Защитные механизмы клетки в условиях загрязнения окружающей среды. // Вестник АН СССР М 1975 № 11 C76-77.

26 Шлык А.А. Определение хлорофиллов и каротиноидов в экстрактах зеленых листьев. В кн. Биохимические методы в физиологии растений/ под ред. О.А. Павлиновой. - М.: Наука, 1971. - С. 154-170.

27 Титова М.С. Реакция пигментной системы сосны обыкновенной (pinus sylvestris 1.) На загрязнение окружающей среды.// Естественные и технические науки . 2010 стр-122-124

28 Е.А. Ерофеева, М.М. Наумова Взаимосвязь физиолого-морфологических показателей листовой пластинки березы повислой с содержанием в ней тяжелых металлов //2010 г. Биология Вестник Нижегородского университета им. Н.И. Лобачевского, 2010, № 1, с. 140-143

\section{References}

1 Tulebaev R.K., Hronicheskaya svincovaya intoksikaciya. - Almaty: Fylym, 1995. - s.9-11

2 Jankiewicz, B. and D. Adamczyk ,2010 Assessing Heavy Metal Content in Soils Surrounding a Power Plant. Short communication, Polish Journal of Environmental Studies, 19 (4): 849-853

3 Mukti Gill. Heavy metal stress in plants: a review. International Journal of Advanced Research ISSN 2320-5407 (2014), Volume 2, Issue 6, 1043-1055

4 Nұrғyzarynov A., Atyraulyқ ekotoptardyң himiyalyқ ekologiyasy (Syrdyң tөmengi ағysy). - Қуzylorda.: «Тұmar», 2003

5 Gworek, B., A. Deckowska and M. Pierscieniak, 2011.Traffic Pollutant Indicator: Common Dandelion (Teraxacum Officinale), Scots Pine (Pinus Silvestris), Small-Leavud Lime (Tilia Cordata). Polish Journal of Environmental Studies, 20 (1): 87-92. 
6 Guevara-Riba A, Sahuquillo A, Rubio R, Rauret G (2004) Assessment of metal mobility in dredged harbour sediments from Barcelona, Spain. Sci Total Environ 321: 241-255.

7 SrinivasaraoCh, Venkateswarlu B, Rattan Lal (2012) Sustaining agronomic productivity and quality of a Vertisolic soil (Vertisol) under soybean-safflower cropping system in semi-arid central India. Canadian Journal of Soil Science 92(5): 771-785.

8 Alghobar MA, Suresha S (2017) Evaluation of metal accumulation in soil and tomatoes irrigated with sewage water from Mysore city, Karnataka, India. Journal of the Saudi Society of Agricultural Sciences 16(1): 49-59.

9 Ansari MI, Malik M (2007) Biosorption of nickel and cadmium by metal resistant bacterial isolates from agricultural soil irrigated with industrial wastewater. Bioresour Technol 98(16): 3149-3153.

10 Aslam J Khan SA, Khan SH (2013) Heavy metals contamination in roadside soil near different traffic signals in Dubai, United Arab Emirates, Journal of Saudi Chemical Society 17(3): 315-319.

11 Tuzhilkina V.V. Reakciya pigmentnoj sistemy hvojnyh na dlitel'noe aerotekhnogennoe zagryaznenie.//Ekologiya, 2009, №4, s. 243-248

12 Artamonov V.I. Rasteniya i chistota prirodnoj sredy. - Moskva: Nauka, 1986. -s.27-34.

13 Romanova SM., Nurahmetov N.N., Bataeva K.O. Ekologicheskie aspekty zagryazneniya toksichnymi veshchestvami poverhnostnyh vod Kazahstana // Himiya. Ohrana okruzhayushchej sredy. Ekologiya cheloveka. - 1997. N4. - S.42.

14 Shalini Arora, C K Jain and R S Lokhande. Review of Heavy Metal Contamination in Soil .International Journal of Environmental Sciences \& Natural Resources ISSN -2572-1119. July 31, 2017. 3Int J Environ Sci Nat Res 3(5): IJESNR. MS.ID.555625 (2017)

15 Davidovich G.T., Sahatov G.S, Davidovich S.G. Regional'noe zagryaznenie prirodnoj sredy Aktyubinskoj obl. // Himiya. Ohrana okruzhayushchej sredy. Ekologiya cheloveka. - 1996. -N3-4. -S.72.

16 Chao Su, LiQin Jiang, WenJun Zhang. A review on heavy metal contamination in the soil worldwide: Situation, impact and remediation techniques Environmental Skeptics and Critics, 2014, 3(2): 24-38 IAEES www.iaees.org

17 Rahypbekov T.K. Rol' gigienicheskih faktorov ekologicheskine blagopoluchnogo goroda v sovershenstvovanii sistemy upravleniya zdravohraneniem. //Avtoreferat kand.dissert. - Almaty, 1996.

18 Savel'ev M.B. Ekofiziologicheskie issledovaniya fitotronov dlya razrabotki metodov kontrolya zagryazneniya vodnoj sredy tyazhelymi metallami./ Vestnik Moskovskogo Universiteta. - 1999. Seriya 16, -N2. -S.42-47.

19 Kabate- Pendias A. Mikroelementy v pochvah i rasteniyah. - M., 1989. -8-204 s.

20 Dubinin N.P., Zasuhina G.D. Zashchitnye mekhanizmy kletki v usloviyah zagryazneniya okruzhayushchej sredy // Vestnik AN SSSR. M., 1975. -N11. -S.76-77.

21 R. PiviC, A. StanojkoviC-Sebi C, D. JoSi C and Z. DiniC . Evaluation of the heavy metals content in soil and plant material at different distances from the motorway E75 in the section Belgrade-PreSevo (SERBIA) .Bulgarian Journal of Agricultural Science, 20 (No 2) 2014, 330-336 Agricultural Academy

22 Bitnerovich A // Ohrana prirody i vosproizvodstva pripodnyh resursov M 1999 № 4 S-45.

23 Bahiev A. Vozdejstvie burevyh rpabot na rastitel'nost'//Vozdejstvie tekhnogennyh faktorov na rastitel'nyj pokrov Karakalpakstana tashkent 1992, S 68-83 .

24 Mikshevich N.V. Koval'chuk L.A. tyazhelye metally v sisteme poseva rasteniya zhivotnye $\mathrm{v}$ zone dejstviya medplavil'nogo predpriyatiya // Mater 2-oj vsesoyuznoj mezhdunaodnoj konferencii po TM v okr i ohr. Prirody M. 1988 g S 127-129.

25 Dubinin N.P. Zasuhina G.D. Zashchitnye mekhanizmy kletki v usloviyah zagryazneniya okruzhayushchej sredy. // Vestnik AN SSSR M 1975 № 11 S76-77.

26 SHlyk A.A. Opredelenie hlorofillov i karotinoidov v ekstraktah zelenyh list'ev. V kn. Biohimicheskie metody v fiziologii rastenij/ pod red. O.A. Pavlinovoj. - M.: Nauka, 1971. - C. 154-170.

27 Titova M.S. Reakciya pigmentnoj sistemy sosny obyknovennoj (pinus sylvestris 1.) Na zagryaznenie okruzhayushchej sredy.// Estestvennye i tekhnicheskie nauki . 2010 str-122-124

28 E.A. Erofeeva, M.M. Naumova Vzaimosvyaz' fiziologo-morfologicheskih pokazatelej listovoj plastinki berezy povisloj s soderzhaniem v nej tyazhelyh metallov //2010 g. Biologiya Vestnik Nizhegorodskogo universiteta im. N.I. Lobachevskogo, 2010, № 1, s. 140-143 